日立鉱山

\title{
Hitachi Mine
}

\section{1. 緒}

\section{言}

位置：日立鉱業所は，茨城県日立市宮田町にあり，鉱 山部門 (本山) は, 常磐線日立駅の北西約 $8 \mathrm{~km}$ 飞位置 し，バスにて約 30 分で達する。

沿革：当鈗山発見の年代は明らかではないが，4 500 年前に発見されたと伝えられる。藩民間による幾多の経 営を経て，1905年 12 月久原房之助翁の手に带し，日立鉱 山と改称し，1918年 1 月久原鉱業株式会社の設立をみ， 当鉱山を基盤としで，各種の事業を営み，1928年社名を 日本産業株式会社と改め, ついで1929年現在の社名であ る日本銨業株式会社と称するにいたった。

日立鉱山が久原䈳の手飞移った翌年1906年より神峰本 坑の探鉱に着手し第 1 神峰（幅 $3 \mathrm{~m}, \mathrm{Cu}$ 品位 $4 \%$ ) V 着眽, 同年ウォーターライナー 5 番さく岩機を用い，第 1 立坑の開さくを開始した。1907年には，第 2 中盛に試 すい第 1 号が印され，また第 4 立坑の開さくも相次いで 行なわれた。以後，明治年間は，中盛神峰，赤沢，高鈴 の上部開発が行なわれて，大鉱山としての基礎が固めら 氺，1912年には第 1 立坑は $300 \mathrm{~m}$ 飞達した。大正年間は 中盛神峰鉣体の下部開発，笹目，入四間の探鉣，赤沢， 高鈴中部の開発が行なわれ第 4 ・第 6 赤沢の富鉙体が発 見された。

また，1913年第 5 立坑，1915年第 6 立坑，1916年150m 通洞の起工が相次いで行なわれ，1916 年第 5 立坑は 150 $\mathrm{m}$ まで完成し，1924年第 1 立坑は $550 \mathrm{~m}$ 亿達した。

昭和にいたり，いよい上生産量も增大の一途を進み, 神峰，赤沢，高鈴の下部探鉱により鉱床賦存範囲が著し く抎大され1931年には第 1 立坑は600mに達した。

支那事变, 第 2 次世界大戦の推移とともに, 生産は飛 躍的に増大し1943年には年間粗鉱 $840,000 \mathrm{t}$, 含銅量 11 , $000 \mathrm{t}$ 亿達した。

終戦後, 着々復興が進められ，1948年 $20,000 \mathrm{t}$ 計画以 来 30,000 t $, 40,000 \mathrm{t}, 45,000 \mathrm{t}$ と合理化計画が 相次 き1962年からは50,000 $\mathrm{t}$ 計画の完了により, 生産の基碟 を固めた。

現状：（第 1，2 表参照）

\section{正会員木塚重治” Shigeji KIZUKA}

第 1 表 粗鉱量と出鉱品位

\begin{tabular}{|c|c|c|c|c|c|c|}
\hline & \multirow{2}{*}{$\begin{array}{r}\text { 粗 钩 量 } \\
(\mathrm{t})\end{array}$} & \multicolumn{2}{|l|}{ 品 } & 位 & \multirow{2}{*}{ 備 } & \\
\hline & & $\mathrm{Cu} \%$ & $\mathrm{Zn} \%$ & S \% & & \\
\hline $\begin{array}{l}\text { 坑内鉱 } \\
\text { 堆積鉱 } \\
\text { 粗铒計 }\end{array}$ & $\begin{array}{r}49,883 \\
6,268 \\
56,151\end{array}$ & $\begin{array}{l}1.25 \\
0.47 \\
1.16\end{array}$ & $\begin{array}{l}0.40 \\
0.46 \\
0.40\end{array}$ & $\begin{array}{r}17.67 \\
6.06 \\
16.38\end{array}$ & & \\
\hline
\end{tabular}

第 2 表 従業員（鉱山部一探査，採鉱，選釷部門一）

42年 3 月現在

\begin{tabular}{|c|c|c|c|c|}
\hline & 坑 内 & 坑 外 & 計 & ，備 \\
\hline $\begin{array}{c}\text { 職 貣 } \\
\text { 涏業貣 } \\
\text { 臨 時 } \\
\text { 訫 }\end{array}$ & $\begin{array}{r}86 \\
893 \\
77 \\
1,056\end{array}$ & $\begin{array}{r}73 \\
250 \\
67 \\
390\end{array}$ & $\begin{array}{r}159 \\
1,143 \\
144 \\
1,446\end{array}$ & 含請負（坑内は起業関係） \\
\hline
\end{tabular}

\section{2. 地質・鉱床の概要}

当鉱山は阿武侵高原の南端脊梁部汇位置し，付近は多 賀山脈を構成し，鉱床の存在する古生層地帯は 300 600 mの山地でやや急峻であるが，その北部に分布する花崗 閃緑岩地域では，標高 $200 \mathrm{~m}$ 位のなだらかな高原性地形 を示している。

日立鎕床は，母岩の片理面に滦济平行に胚胎する，い わゆる層状含銅硫化鉄鈗床であるが，母岩の種類，母岩 の性質，母岩の変成状態，鎕床の形，鉣石の性質等が非 常に変化㨽み，きわめて複雑な鉱床で三波川変成岩中 の別子型キースラーガーに対し, 日立型キースラーガー と呼ばれる。

鉣床は注とんぞ疑灰岩，集塊岩類の変成岩中に存在 し，そのうち主な鉱床は，日立本鉱床带でこれを入四 間, 藤見, 䈎目, 中盛, 神峰, 本坑, 赤沢, 高鈴の 8 鉱 床 (鉱床群) に大別している。この注かに, 神峰鉱体よ り約 $1.8 \mathrm{~km}$ 東に神峰本沢不動滝鉱床带があり,ここに大 雄抢よび不動滝鉣床が，さらに高鈴鎕床の南東約 $4 \mathrm{~km}$ のところに諏訪鉱床帯が㐫り, 前山, 永盛の 2 鉱床（鉱 床群)が㐫る。

\section{3. 採 掘 法}

\section{$3 \cdot 1$ 採掘法の変せんおよびその採用の理由}

当所の鉱床は，鉱体抢よび母岩の性状にる種々差異は 岁るが一般的にいって採鉱に際しては支保作業を多く要 する。 


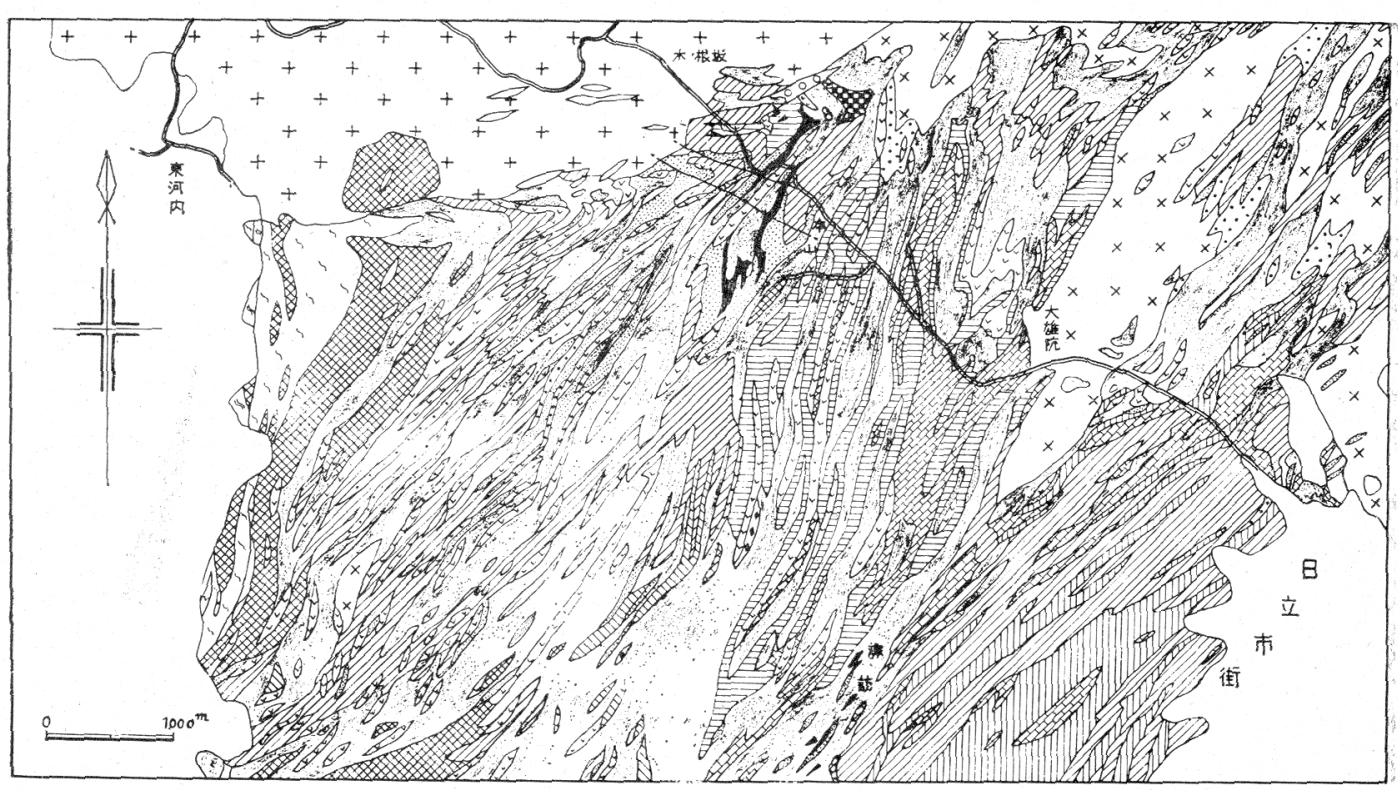

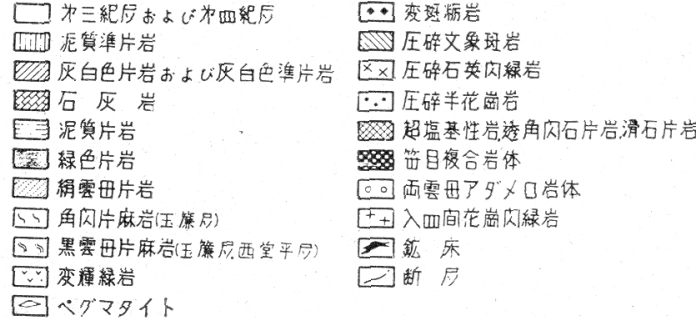

第1図日立鈗山地質図

各鉱床は平均 $2 \sim 4 \mathrm{~m}$ の脈幅を有し, 採掘は銿の方向 に沿って，上盤加ら下盤采で脈幅一杯汇行ない，脈幅の 広い部分は $2 \sim 3$ 加临に分けて上盤側上り順次採掘を行 なう。加背幅注通常無支柱掘 (平歩合) では $4 \sim 5 \mathrm{~m}$,

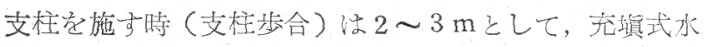
平段欠法が用いられている。

当初, 充填材には探開ズリ和よび選鉿廃石, 重選浮鈸 を利用していたが，昭和 27 年浮選廃湾によるスライム充

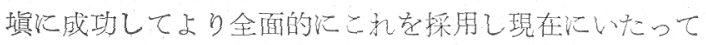
いる。従来注上向採掘法を採用していたが，軟弱な切羽 に対して, 下向採掘法の研究を始め, 極めて好成績を収 めることがでさたので逐次この方法汇切替光, 現在採掘 切羽0 $65 \%$ 怯, 本法炕上り行板って打可採掘能率, 保安

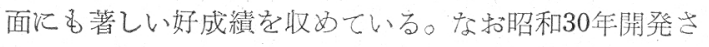
れた藤見鈜体は, 母岩, 鈗脈之もに比䡆的堅硬であるの で，上向充填採掘法を採用し 20 ３0 $\mathrm{H}$ の電動スラッシャ なた注タイヤローダ等を採用している。

\section{$3 \cdot 2$ 現在の採掘法の種類}

(1) 下向充壃採掘法

上部坑道より下方に向って採堀していくるので, 当所

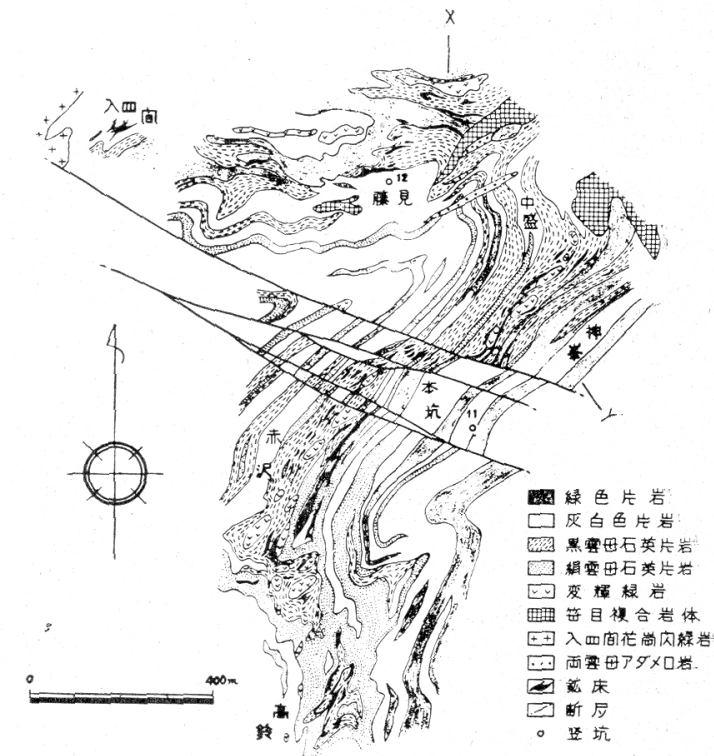

第2 図日立鉱山 $300 \mathrm{~m}$ L 地質図

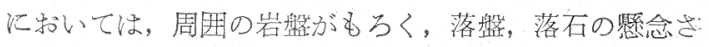
れる個所飞用いている。この方法は天盤をサンドスライ ム汇置換し, 均等な荷重を大引村押木で受けるために, つぎのような利点がある。

利点：(1) 保安上, 人工的天盤なので上部よりの落盤・ 落石の恐机がない。(2) 支柱作業, 浮石点検作業が簡単 にでさ時間が短縮される。(3) スクレーパの使用が容易 （踏前が鉱石でズリの搔込及がない）。(4) 支柱作業汇 高度の技術走要しない。(5) 踏前に粉鉱が抟らない。

欠点：(1) 坑木の使用が平歩合, 掛矢切羽に比して多 いので経費高で西る。(2) 緩傾斜, 絊脈, 不規則鉱体飞. 

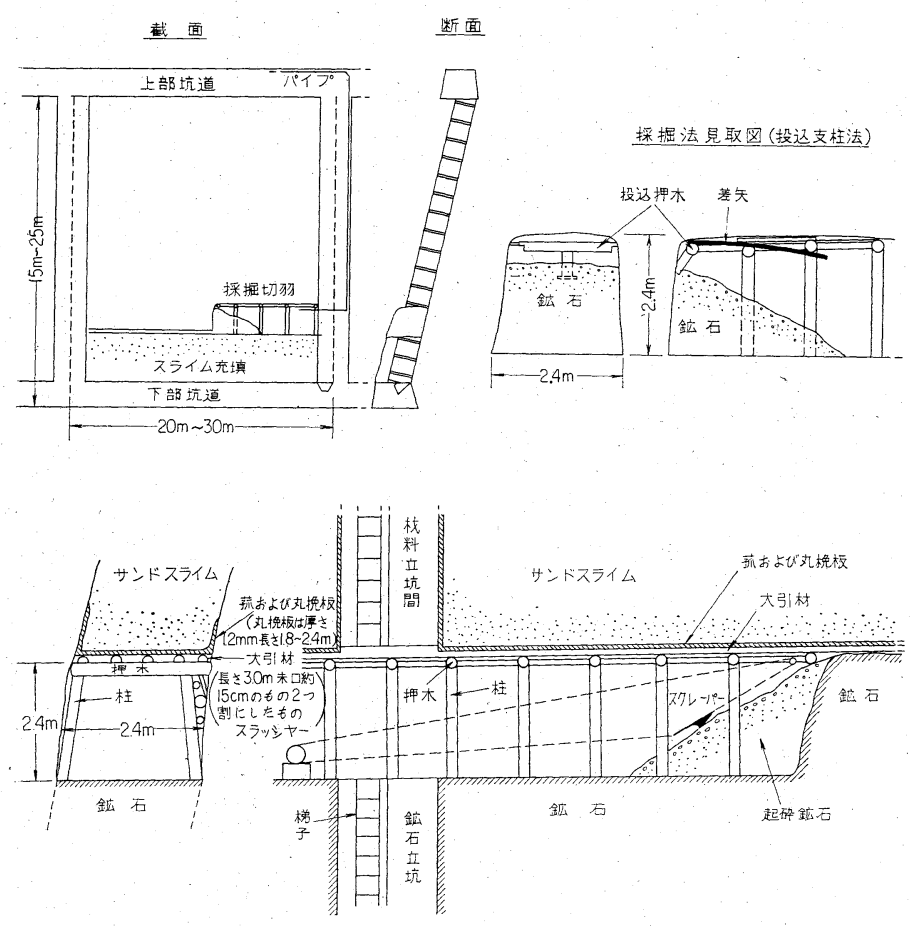

第 3 図 下向採掘法
(1) 鉱画範囲も状沉により更に長くとることも ある
（2）無支柱切羽の場合に加脊幅は鉱石幅に応し て盤の状況をみて広く採掘するときがある
(3) 支柱切羽において子状況に応じ投込及支柱 法で行なわないときもあり, 加答幅も広くと る場合もある
（4）上記の加蓨幅，高さ，状況により多少広く または狭くする場合もある

第 4 図上向採掘法

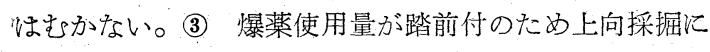
比して若干多い。

\section{(2) 上向充填採掘法}

比較的堅硬な個所に対する採掘に適している。当所に 特いては，新しく開発された藤見鉱体はこの方式を採用 している。

利点：(1) 坑木が下向採掘法より少なくてすむ。

(2) 鉱体が不規則であってもとれに応じて採掘ができ， 鉣石が無駄なく掘れる。

（3）その核藤見鉱体の一部を対象にサブレベルスト 一ピング法を試験的に実施する計画でいる。

\section{3 採掘準備}

上下間隔15～25m，鉱体延長30～50mを 1 採掘区画と

乙適宜の位置に上下連絡の掘上りを開さくする。

上向の場合は：(1) 鉱体の膨縮に応じて腰割り後, 冠 打ち採掘をする。

（2）鉣石連般坑道として切替え坑道を作る。

(3) 適宜の個所に鉱石漏斗口を作る。

下向の場合は銿押纣道に下向用マットを施して下向に 移るか, 上部を採掘中のものは上部坑道の踏前に $1 \sim 2$ 加脊の竜頭を置いて下向に入るのが普通である。

\section{3·4、せん孔，発破}

採掘切羽のせ九孔は，LDH-340さ岩機 $(30 \times 8 \times$ $15 \mathrm{~mm}$ mーアロイインサートビット, ロッド $\mathrm{CR}_{2} 22 \mathrm{~mm}$ QO，LTS）を使用しせん孔する。せん孔本数は切羽の
状況により異なるが通常 8 〜 12 本を水平方向に 0.60 $1.00 \mathrm{~m}$ 間隔に $1.0 \sim 1.2 \mathrm{~m}$ 深さで $2 \sim 3$ 列にさく孔する が, 平歩合切羽 (支保の必要ない切羽) の条件の良いと ころでは，50〜100本もせん孔するときもある。

発破は，特定の個所以外は压とえどが電気発破法でD $\mathrm{S}$ 電気雷管を使用している。ダイナマイトは 3 号桐 100 $\mathrm{g}, 25 \mathrm{~mm} \phi$ で $\mathrm{AN}-\mathrm{FO}$ と併用している。 $\mathrm{AN}-\mathrm{FO}$ は 採掘使用の $45 \%$ を占めている。

\section{$3 \cdot 5$ 切羽積込}

切羽での積込方法は手積, バケットローダ, タイヤロ 一ダ，スラッシャなどで行なっており，機械化による出 鉱比率は全出鉣量の $90 \%$ である。

\section{6 採掘切羽支保}

採掘切羽の支保は, 坑木によるものが汷とんど松材括 よび雑木を使用している。そのほか, 鉄柱 (約 1,600本) 特よび鉄板坑井を使用し，坑木の代替支保材として使用 している。

\section{7 切羽充坥}

切羽充填はすべてサンドスライム充填で, 月平均約 $20,000 \mathrm{~m}^{3}$ (流送濃度 $63 \%$ ) 支充垻している。

充填材としては, 浮選廃さいのみでは不足となるので 坑内より出る探開ズリ，あるいは重選浮鉣を破砕し月約 9,000 t 学補い, 選鉱廃さいスライムと混合し坑内充填 に使用している。

\section{$3 \cdot 8$ 切羽の人員配置}


第 3 表 採掘法別出鉱量打よび切羽数

(42年 3 月現在)

\begin{tabular}{l|c|c|c|c}
\hline 採掘法の種類 & 出 鉱 量 & 出鉣比率 & 切羽 数 & 備 \\
\hline 充填段欠法 & $46,793 \mathrm{t}$ & $100 \%$ & 86 & \\
\hline
\end{tabular}

第 4 表 開探鉱出鉱量拉よび試錐延長

(42年 3 月実績)

\begin{tabular}{|c|c|c|c|c|c|}
\hline \multirow{2}{*}{ 試錐姃長 } & \multirow{2}{*}{ 探鉣延長 } & 出 & 鉱 & 量 & $(t)$ \\
\hline & & 開探鉱 & 採 & 鉱 & 訫. \\
\hline $1,143.75 \mathrm{~m}$ & $1,017.48 \mathrm{~m}$ & 3,090 & & 793 & 49,883 \\
\hline
\end{tabular}

作業人員は支柱員, さく岩員, 運鉱員を切羽の条件比 応じて組合せ，通常 2 名を原則としたクルーシステムに よる出鉱 $\mathrm{t}$ 数請負としている。

\section{4. 運搬}

\section{$4 \cdot 1$ 鉱石運搬}

中段坑道の運盤は，人力運般を主とし，一部において はスラッシャを使用して鉱石を立坑を経て主要運般坑道 に集約する方法を採用している。主要運般坑道は, 蓄電 池機関車を使用し，藤見鉱体を除くほかの鉱体はNo.11 立坑に，藤見鉱体はNo.12立坑より巻上げ，No.11立坑 坑外鉱舎に最終的に集約し，これよりベルトコンベヤに て選鉱場汇運般される。

\section{$4 \cdot 2$ ズリ運搬}

坑内の探開ズリはNo.1, No.12 立坑で坑外に巻上げ 粉砕工場に送り, 充填材として利用するほか, 研石とし て販売している。

\section{3 人員運搬}

人員の入出坑は No.1, No.6, No.11, No.12 使 用している。さらに $550 \mathrm{~m} \mathrm{~L}$ に入四間立坑, 拉よび No. 13 立坑 (近時完成予定) があり，下部開発要員はこの立坑 を利用している。

\section{$\mathbf{4 \cdot 4}$ 材料運搬}

材料運搬はNo.6，No.11，No.12 立坑を主力にして 行なっている。その汪か No.1，入四間立坑も一部利用 しているが少量である。

\section{5. 通気，排水，照明，保安}

\section{$5 \cdot 1$ 通 気}

当所では，昭和 26 年までは自然通気のみを行なってい たが，その後の採掘の進行とともに漸次高温多湿とな り，作業能率に著しく影響してきたため，昭和27年扇風 機による強制通気方式を採用し，東部方面 $100 \mathrm{P}$ ，西部 方面200Pの扇風機を設け，総通気量約 $7,000 \mathrm{~m}^{3} / \mathrm{min}$ 得ているが末端高温切羽 $\left(28^{\circ} \mathrm{C}\right.$ 以上) には， $1.5 \mathrm{~kW}$ 局 部扇風機を設置して，感覚温度の低下を計っている。

第 $\mathbf{5}$ 表 採掘法別工程単位和よび直接採掘・採鉣費

（昭和 41 年 4 月 42 年 3 月実績)

\begin{tabular}{|c|c|c|c|c|c|c|c|c|c|c|c|c|c|c|c|c|c|c|c|c|}
\hline \multirow{2}{*}{$\begin{array}{c}\text { 採 } \\
\text { 揚 } \\
\mathrm{t} / \text { 月 } \\
\end{array}$} & \multirow{2}{*}{$\begin{array}{c}\text { 充 } \\
\text { 填 } \\
\text { 量 } \\
\mathrm{m}^{3} / \mathrm{t}\end{array}$} & \multicolumn{3}{|l|}{$I$} & \multicolumn{4}{|c|}{ 原単位（粗鈗垴たり） } & \multicolumn{4}{|c|}{ 直接採掘費（垴たり） } & \multicolumn{4}{|c|}{ 直接採鉱蒷（十あたり） } & \multicolumn{4}{|c|}{ そ の 他 } \\
\hline & & 採掘 & 充填 & 訫 & 工数 & 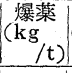 & $\left|\begin{array}{c}\text { 沉木 } \\
\left(\mathrm{m}^{3}\right. \\
(\mathrm{t})\end{array}\right|$ & $\left|\begin{array}{|c}\text { 電力 } \\
\mathrm{kWh} \\
\text { /t) }\end{array}\right|$ & 人件 & 物品 & その他 & 訫 & 人件 & 物品 & その他 & 計 & 人件 & 物 品 & その他 & 䛸: \\
\hline 333 & 0.437 & $7,646.7$ & 900.2 & $8,546.9$ & 0.189 & 0.328 & 0.019 & 37.1 & 640 & 315 & 399 & 1,358 & 1,279 & 429 & 841 & 2,549 & 639 & 110 & 442 & 1,191 \\
\hline
\end{tabular}

採掘量は探鉝崭銶を除く

第 6 表 坑内 ポソプ主 要 仕 様

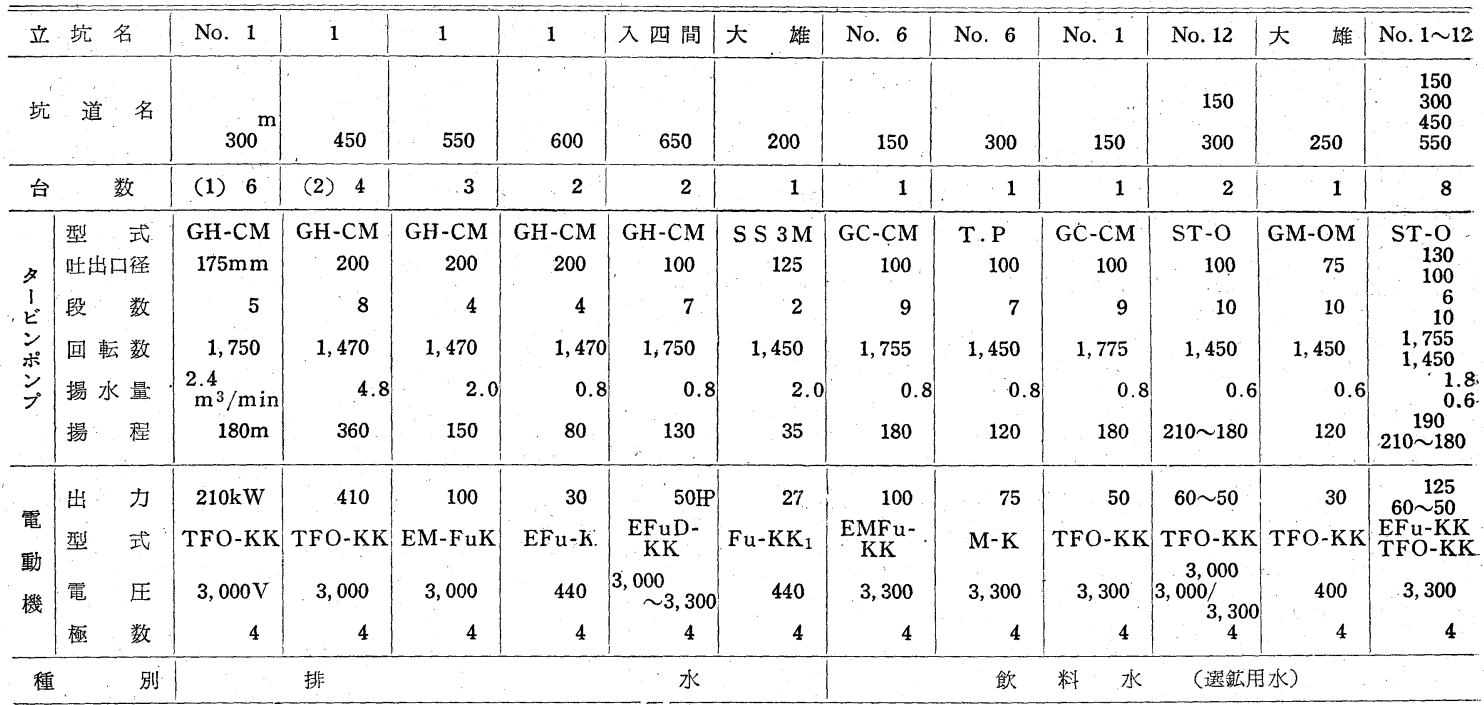

坑内水の成分 $\mathrm{pH}$ 值 $3.0 \sim 4.0 \quad \mathrm{Free} \mathrm{SO}_{3} \quad 40 \sim 80$ 


\section{$5 \cdot 2$ 排 水}

坑内水は上部坑水，すなわち $0 \mathrm{~m}$ 準坑道以上のものは 各坑口を経て，選釷場に導き選鉱用水として使用する。 中部坑水，すなわち $0 \mathrm{~m}$ 以下 $150 \mathrm{~m}$ 坑道までの坑内水は $150 \mathrm{~m}$ 坑道に流下集水し，下部坑水すなわち，150mより 下部の涌水は, $300 \mathrm{~m}, 450 \mathrm{~m}, 550 \mathrm{~m}, 650 \mathrm{~m}$ の各坑道に 設置するポンプによって $150 \mathrm{~m}$ 坑道まで揚水し，中部坑 水を合して $150 \mathrm{~m}$ 踈水坑道を経て，大雄院に導く。ただ しその一部を必要に応じて $0 \mathrm{~m}$ 亿揚水し選鉱用水の補給 として使用している。な扔，別系統で飲料水として揚水 を行なっているるのもある。

41 年上期の涌水量は月平均 $450,461 \mathrm{~m}^{3}$ であった。

\section{$5 \cdot 3$ 照 明}

当所の坑内照明は, 立坑プラットおっひび主要運般坑道 は活とんぞ電灯照明を行なっている。

採掘切羽の照明は機械化 (ローダ, スラッシャ) 個所 には, 電灯線 (キャップタイヤ)により直接アイランプ を取付け照明を行なっている。電灯線のない個所では, フラッドライトを使用し切羽照明を行なっている。その 他坑内全員湴キャップランプを使用している。

\section{$5 \cdot 4$ 保 安}

保安推進運動の方策として，全山的にはつぎのことを 実施している。

(1) 保安衛生の日

毎月 1 日を保安衛生の日と定め, 安全祈願, 職場の整 理清掃, 総員の点検, 保安一口報告全員参加を実施する。

(2) 無災害競争

各職場単位に目標（無災害日数）を定め達成したとき 飞表彰する。

（3）保安一口報告運動

各人より保安の改善事項, 意見, 経験; 希望等を提案 させ優秀なものについては揭示をし，一般に知らせると ともに賞品を支給す。な提案件数に応じてそれぞれ賞 品を支給している。

(4) 、ルールを守る運動の推進

規則, 規程の実態調查, 保安規程の内容で標準類にも れているものの調査, 特よび委員または，係員を中心と したグループによるルールの内容検討によりルールの修 正整備をし，作業員が守りやすいルールを確立し作業員 が参加して決めたルールを作業員が自主的に守ることに より保安の確保に当たる運動を推進中である。

(5) 職場小グループ制による自主保安推進運動 全山の運動方針のひとつとしてロス防止運動が展開さ れているがこれには, 各職場で10名内外の小グループを 編成してグループ活動を主体にロス防止改善提案, 自主 保安とすべて作業員のリーダになるるのが, 自主的に運 動を進め, 提案事項をグループ単位に提出し保安面, ロ
ス防止の運動展開を行なっている。な特グループ提案の

優秀なものについては表彰がされる。

(6) 保安巡視

保安委員による各職場の巡視を行ない, 設備教育等の 保安面について指摘提案を行ない, 審議検討し, 改善, 教育にあたっている。

その他，各課それぞれ上記以外飞毎月目標を定め, 保 安運動を行なっている。

\section{6. 問題点と将来計画}

\section{1 問題点}

（1）若手の学働者の確保 (2) 坑内作業員の老令化

(3) 切羽充填の際のスラライム流出防止 (4) 下部開 発飞伴弓通気量の確保 (5) 坑木節減対策と代替品 の利用 (6) 係員を含めた作業者の保安向上対策

（特にルールを守る自主保安）（7）切羽の集約化

(8) 外部探鉱化伴了涌水対策

\section{2 将来計画}

(1) 下部地帯を含め総合的な通気対策（藤見鉱体 を主とした）（2）採掘切羽用に坑木にかわり, 油 压鉄柱の使用 (3) 大型採掘切羽の設定に上る切羽 数の隇（切羽の集約化）(4) 維持坑道延長の削減 と保坑費の減（5）運搬の集約合理化

第 7 表，過去 10 年間の年間粗鉱量, 平均品位 和上び能率 (坑内, 全山) の推移

\begin{tabular}{|c|c|c|c|c|c|c|c|}
\hline \multirow{2}{*}{ 年度 } & \multirow{2}{*}{$\begin{array}{l}\text { 年 間 } \\
\text { 出鉣量 } \\
(\mathrm{t})\end{array}$} & \multicolumn{3}{|c|}{ 平均品位 $(\%)$} & \multicolumn{2}{|c|}{$\begin{array}{l}1 \text { 人 } 1 \text { 力月 } \\
\text { 出 鉱 量 }\end{array}$} & \multirow{2}{*}{ 備 } \\
\hline & & $\mathrm{Cu}$ & $\mathrm{Zn}$ & $\mathrm{S}$ & $\begin{array}{r}\text { 坑内 } \\
(\mathrm{t})\end{array}$ & $\begin{array}{l}\text { 全山 } \\
(\mathrm{t})\end{array}$ & \\
\hline $\begin{array}{l}32^{\text {年 }} \\
33 \\
34 \\
35 \\
36 \\
37 \\
38 \\
39 \\
40 \\
41 \\
\text { 許 }\end{array}$ & $\begin{array}{r}485,247 \\
515,258 \\
541,997 \\
562,682 \\
602,859 \\
605,559 \\
623,373 \\
617,256 \\
626,642 \\
611,675 \\
5,792,548\end{array}$ & $\begin{array}{l}1.04 \\
1.03 \\
1.00 \\
0.97 \\
1.04 \\
1.06 \\
1.08 \\
1.09 \\
1.10 \\
1.16\end{array}$ & $\begin{array}{l}0.71 \\
0.71 \\
0.59 \\
0.73 \\
0.70 \\
0.60 \\
0.57 \\
0.60 \\
0.61 \\
0.54\end{array}$ & $\begin{array}{l}18.39 \\
18.03 \\
17.98 \\
17.93 \\
18.04 \\
17.48 \\
17.14 \\
17.48 \\
17.20 \\
17.52\end{array}$ & $\begin{array}{l}32.7 \\
35.2 \\
37.2 \\
37.8 \\
38.1 \\
40.5 \\
43.0 \\
43.5 \\
47.8 \\
50.4\end{array}$ & $\begin{array}{l}19.3 \\
20.7 \\
22.1 \\
23.2 \\
27.0 \\
27.0 \\
30.9 \\
32.5 \\
36.4 \\
36.8\end{array}$ & 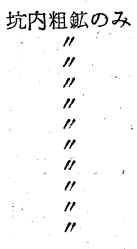 \\
\hline 平均 & 579,255 & 1.06 & 0.83 & 17.69 & 40.3 & 26.7 & \\
\hline
\end{tabular}

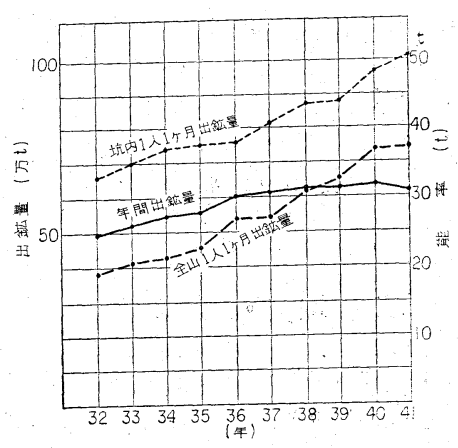

第５図 